IZA DP No. 4317

Understanding the Workweek of Foreign Born Workers in the United States

Fernando A. Lozano

July 2009 


\title{
Understanding the Workweek of Foreign Born Workers in the United States
}

\author{
Fernando A. Lozano \\ Pomona College, University of Michigan \\ and IZA
}
Discussion Paper No. 4317
July 2009

IZA

P.O. Box 7240

53072 Bonn

Germany

Phone: +49-228-3894-0

Fax: +49-228-3894-180

E-mail: iza@iza.org

\begin{abstract}
Any opinions expressed here are those of the author(s) and not those of IZA. Research published in this series may include views on policy, but the institute itself takes no institutional policy positions.

The Institute for the Study of Labor (IZA) in Bonn is a local and virtual international research center and a place of communication between science, politics and business. IZA is an independent nonprofit organization supported by Deutsche Post Foundation. The center is associated with the University of Bonn and offers a stimulating research environment through its international network, workshops and conferences, data service, project support, research visits and doctoral program. IZA engages in (i) original and internationally competitive research in all fields of labor economics, (ii) development of policy concepts, and (iii) dissemination of research results and concepts to the interested public.
\end{abstract}

IZA Discussion Papers often represent preliminary work and are circulated to encourage discussion. Citation of such a paper should account for its provisional character. A revised version may be available directly from the author. 


\section{ABSTRACT}

\section{Understanding the Workweek of Foreign Born Workers in the United States*}

I analyze the length of the workweek of foreign-born workers in the U.S. I concentrate on workers supplying long hours of work - 50 or more weekly hours and document that immigrants are less likely than natives to work long hours. Surprisingly, these differences are greatest among highly educated and salary paid workers, and persists even after conditioning for demographic characteristics. I explain these differences with two within occupation characteristics. First, relative to natives, immigrants are less likely to supply long work weeks if they work in occupations where the immigrant-native earnings differential is big. Second, immigrants are also less likely to supply long work weeks when they work in occupations with a wide dispersion of earnings. This second result is important, because the occupation dispersion of earnings has been used to characterize changes of the worker's earnings over the worker life cycle (Bell and Freeman, 2001; Kuhn and Lozano, 2008), and a good measure of the incentives to supply long hours of work.

JEL Classification: J22, J61

Keywords: immigrants, hours of work

Corresponding author:

Fernando A. Lozano

425 N. College Ave

Carnegie 215

Claremont, CA 91711

USA

E-mail: fernando.lozano@pomona.edu

\footnotetext{
" I want to thank Arturo Gonzalez, Peter Kuhn, Craig Mclntosh, Marie Mora, and Todd Sorensen, as well as two anonymous referees, for their helpful comments and suggestions. I also want to thank participants at the Brown Bag Seminar at Claremont McKenna College, at the 2006 Society of Labor Economics Meetings in Boston MA and at the 2007 Meeting of the Australasian Meetings of Labor Economics for their helpful comments. Part of this manuscript was completed when I was a visitor at the Economics Program of the Research School of Social Sciences at The Australia National University, I am grateful for their hospitality. This research was supported in part by a grant from the Ford Foundation to the Research and Training Program on Poverty and Public Policy at the University of Michigan. All errors remain mine.
} 


\section{Introduction}

Today, foreign-born workers shape the United States' labor market. The US Census Bureau reports that more than 30 million people currently living in the United States were born abroad. Not surprisingly, economists have paid considerable attention to this group, and previous work spans from their labor market performance (for example Chiswick 1977, Borjas 1985, 1995 among many others) to their fertility decisions (Gordon and Macintosh, 2006). Nonetheless, little attention has been paid to the length of the workweek of foreign-born workers, and whether it differs from that of the native-born. While the conventional stereotype in the popular press is that immigrants tend to work very long hours (for example DeConto, 2006 or Porter, 2006) this issue has yet to be examined in depth.

Simultaneously, economists have been interested in understanding the consequences of workers' long hours of work, and showed substantial evidence that working long hours is an important determinant of future earnings growth. For example, using data from the U.S. and Germany, Bell and Freeman (2001) show that hours of work are positively related to a workers' earnings growth and future promotions. Further, and in a different paper, Bell and Freeman (1996) show that American workers perceive that hours of work in the present will determine their earnings in the future. Similarly, Bratti and Staffolani (2007) use British household data to show that higher hours of work are positively correlated with an increased probability of attaining a promotion, even after controlling for worker heterogeneity. Perhaps, this is because long hours of work may work as a signal of the worker's commitment to the firm and effort.

Not only do long workweeks relate to future earnings and other labor market opportunities, but understanding the supply of hours is important to understand overall worker's welfare. Failing to account for weekly hours of work may distort welfare analyses. For example, as Johnson and Kuhn (2004) point out, if high income earners tend to supply longer hours, then increasing earnings inequality may overstate welfare inequality as leisure is a normal good. Finally, and as Kuhn and Lozano (2008) point out, understanding the trade off between leisure and market labor is important as this allows us to better understand the quality and rhythm of someone's life. 
The goal of this paper is to document and explain any differences in the number of weekly hours of work between foreign-born and native workers. Following Kuhn and Lozano (2008), I focus on one dimension of labor supply: workers supplying 50 or more hours per week (I will refer to these workers as those supplying long hours hereafter). This contrasts with the previous literature on immigrant labor supply, which concentrates, for example, on family labor supply (Beker and Benjamin, 1988; Blau et al, 2003) or annual hours of work (Blau and Kahn, 2006). My results show that differences in the workweek between immigrants and natives differ across hourly and salary paid workers: after controlling for demographic characteristics, hourly paid immigrants are as likely to work long hours as their native counterparts, but long hours differences still persist among salary paid workers.

Given this - perhaps surprising - result, I present two empirical results that potentially explain these differences: 1) Within occupation native-immigrant's differences in hours of work are greatest in occupations where earnings differences between these groups are greatest; 2) Immigrants are less likely to supply long weekly hours in occupations where the residual earnings dispersion (net of demographic characteristics) is greatest. The first result is not surprising, and is consistent with traditional labor supply models where hours of work depend on the worker's contemporaneous earnings. But the second result is, since earnings inequality is not typically associated with traditional labor supply analyses, and has only recently been adapted by labor economists (see Bell and Freeman, 2001 or Kuhn and Lozano, 2008).

The basic argument for using inequality as a determinant of labor supply is that hours in period $t$ will be positively associated with earnings in period $t+1$, perhaps because longer workweeks raise the worker's future position on the within occupation earnings distribution. A wider spread of the earnings distribution will in turn increase the incentive to supply long hours. As in the previous literature, I assume that the within occupation earnings inequality is a good approximation for the slope of a worker's lifetime earnings, and this is an important metric as it captures the future rewards from working long hours. Heuristically, this is not different to tournament theory (Lazear and Rosen, 1981) in a work setting where workers' rewards are determined by the workers' relative outcomes, or to efficiency wages (Fehr et al, 1998) where higher wages are used to exert optimal effort from the 
worker. Again, the basic intuition is that as the within occupation earnings inequality widens, so will the incentive to supply long hours. Further, these incentives will differ between hourly paid and salary paid workers: hourly paid workers' input is verifiable by the employer and can be rewarded on concurrent compensation, but such is not the case for salary paid workers, where individual output is observed only in the long run and effort not verifiable by the employer (Fama, 1991).

If earnings inequality does capture the future stream of a worker's income, then this metric should be at least as important to determine an immigrant worker's labor supply as the contemporaneous wage is. If an immigrant worker perceives a positive probability of job separation because of either temporary or permanent return migration to the source country (Borjas and Bratsberg, 1996; Lubotsky, 2007), or further migration within the host country (DeVanzo, 1983), then the expectation of future migrations will change the slope of the worker's lifetime expected earnings and thus change the incentives to supply long hours. Intuitively, my argument follows the results presented either by Borjas (1982), Dustmann (1993) or Cortes (2004). Borjas explores the rate of economic mobility of Hispanic immigrants in the U.S. and argues that Cuban immigrants - political refugees - are more likely to invest in the host economy because they face higher costs of return migration than other immigrants do. Dustmann argues that temporary migrants are less likely than permanent migrants to invest in host-country specific human capital, and using German data shows that temporary migrants show flatter earnings assimilation profiles as years in the host country increase. Cortes (2004) shows that refugee migrants - with longer expected time horizon in the host country, and thus higher incentive to invest in host country skills - have steeper wage assimilation profiles than economic immigrants and work on average more annual hours. The results in this paper are similar to those in this literature: differences in hours of work between salary paid immigrant and native workers persist in occupations with wide earnings inequality. This suggests that an immigrant worker's shorter expected time horizon in the source country attenuates the incentives to supply long workweeks.

This paper highlights the importance that occupation characteristics have on an immigrant's time allocation between market labor and leisure. Particularly important is the ability to accrue future 
rewards from working long hours today. To the extent that current hours of work determine future labor market outcomes, it is important to consider any differences between immigrant and native workers in their incentives to supply long hours, as these will most likely determine the workers' future prosperity and immigrants' earnings assimilation profile.

\section{Data}

The main dataset in this paper is the 1994-2006 NBER Collection of the Current Population Survey Outgoing Rotation Groups (CPS ORG hereafter). This survey includes a battery of questions regarding the respondents labor market activity, among them and exclusively in the Outgoing Rotations, weekly earnings and whether the worker is salary or hourly paid. This survey has two added advantages: it is collected continuously during the year, which makes it less sensitive to seasonal variations in labor supply, and the number of observations is three times greater than the regular CPS survey.

The main measure of labor supply in this paper is an indicator variable that takes a value of one if the worker supplies 50 or more weekly hours in his main job, and zero otherwise. Concentrating on workers supplying 50 hours or more has several advantages: first, my analysis focuses on the upper tail of the distribution of hours worked, which gives a better idea of a worker's tradeoff between leisure and labor market activity. Second, focusing on the length of the workweek is a better measure of a workers willingness to supply high on-the-job effort. Third, this measure avoids problems due to clustering of responses around one number, for example when respondents round their hours of work to 40 hours per week. Finally, this measure is robust to temporary unemployment spells, and vacation time.

In contrast to the previous literature which uses annual hours (Cortes, 2003 or Blau and Kahn, 2007 ) it can be argued that weekly hours of work captures a different dimension in the margin of a worker's labor supply decision. It is important to consider the differences in the marginal incentives to supply an extra hour between two workers who supply the same amount of hours with different intensities, for example one supplying 1980 annual hours by working 36 weeks at 55 hours per 
week, versus another immigrant working 40 hours a week for 50 weeks. Further, in the CPS annual hours are computed using weeks worked multiplied by usual weekly hours. One last advantage of analyzing weekly hours is that the question for weeks worked in the Decennial Census or in the March Supplement of the Current Demographic Survey includes weeks of paid vacation and paid sick leave, and as Coleman and Pencavel (1993) claim information of weeks worked indicates firms' cost of employing workers more accurately than it does actual time worked.

The sample used in this paper is restricted to men. I choose to focus my analysis on men because selection of weekly market hours by immigrant women is not random and likely to be more sensitive to their partner's income. I restrict age to the 25-64 range since by this age presumably most workers ended their investments in education. My control group throughout the paper is all US born men, without distinction to ethnic group. Further, to avoid biases arising from including immigrant children in the sample, the immigrants sample is composed of those immigrants who arrived in the United States at age 16 or older. All monetary units are in 1994 dollars. Also, in this paper I interchange the terms foreign-born with immigrant freely.

Table 1 presents the sample's summary statistics and the proportion of men in each group who work long hours. The first and third columns refer to US natives. The second and fourth columns refer to foreign-born workers. Focusing on the sample means, immigrants are less likely than natives to have a college degree and more likely to be high school dropouts - $35 \%$ of immigrants do not have a high school degree while $29 \%$ of them have a college degree. Also, immigrants are more likely to be younger than natives. Finally, foreign-born workers are 10 percentage points less likely to be salary paid than natives and they are also less likely to be unionized.

Concentrating on the incidence of working long hours, native workers are more likely to work long hours than immigrants do. Perhaps surprisingly, these differences are greatest are among middle aged, salary paid and highly educated workers. For example, among high school dropouts, natives are 5 percentage points more likely to work long hours than immigrants. Among college graduates, native workers are 11 percentage points more likely to work long hours. Among salaried paid workers, natives are 11 percentage points more likely to work long hours than immigrants; among hourly paid 
workers, natives are only 4 percentage points more likely to work long hours.

Similarly, Figure 1 presents the proportion of workers working long hours by the wage quintile of all working men. The left panel shows the proportion among all workers whose workweek is 50 hours or longer and the right panel restricts the sample only to salary paid workers. Surprisingly again, immigrants who belong to the highest quintile of the wage distribution are 10 percentage points less likely to work long hours than native-born workers in the same income category. In contrast, the difference between immigrants and natives who are in the lowest wage quintile is only 1 percentage point. If the sample is restricted to salary paid only the difference among the highest paid workers is 12 percentage points, the difference among lowest earners is only 5 percentage points. While it is interesting to note that immigrants are less likely to work long hours than natives who earn similar wages, one must be aware that these averages are unconditional, and perhaps they reflect demographic and occupational differences, an issue to which I turn next.

\section{Differences due to Demographic Characteristics}

The first exercise in this paper is to analyze to what extent the differences between immigrants and natives in the probability to work long hours are explained by differences in demographic characteristics. Particularly I test whether the number of years an immigrant has spent in the US change the worker's probability to supply long hours. Ex-ante, it is not clear how years in the United States would affect the workweek of foreign-born workers. It may be that as experience in the host country is correlated with higher earnings (Chiswick, 1977; Borjas, 1985, 1995) and higher earnings increase the opportunity cost of leisure, so will the probability of a long hours workweek will increase. But, it is also not clear how selective non-random temporary and permanent out-migration (Borjas and Bratsberg, 1996; Lubotsky, 2007) may determine the workweek. For example, if an immigrant has a target level of savings and will work long hours until the target is attained, and then returns to the source country, then recent immigrants should work much longer hours than earlier ones. Conversely, if immigrants that are more likely to stay longer in the U.S. are more driven, then workweeks for earlier arrivals should be longer than for recent ones. 
To analze this I use Borjas $(1985,1995)$ cohort analysis. My baseline specification for working long hours $l h_{i t}$, for person $i$ in year $t$ is estimating the following linear probability model ${ }^{1}$.

$$
l h_{i t}=\alpha+\sum_{h=1}^{6} \delta_{h} C_{i t}^{h}+\sum_{k=1}^{4} \beta_{k} D_{i t}^{k}+\epsilon_{i t}
$$

where $C_{i t}^{1}$ represents an observation $i$ in year $t$ who arrived in the 1960 to 1979 cohort; $C_{i t}^{2}$ represents those who arrived between 1980 and 1985; $C_{i t}^{3}$ represents those who arrived between 1986 and 1991; $C_{i t}^{4}$ represents those who arrived between 1992 and 1995; $C_{i t}^{5}$ represents those who arrived between 1996 and 2000; and $C_{i t}^{6}$ represents those who arrived between 2001 and 2006. The parameters of interest are $\beta_{1}$ to $\beta_{4}$, and these are associated with the coefficients of dichotomous variables that represent an immigrants time spent in the United States: $D_{i t}^{1}$ represents that immigrant $i$ in survey $t$ has been in the US between 0-5 years, $D_{i t}^{2}$ represents those who have been in the US between 6-10 years, $D_{i t}^{3}$ represents those who have been in the US 11-20 years, and $D_{i t}^{4}$ represents those who have been in the US more than 20 years. Note that the reference group for the above coefficients is native-born workers, and the estimate of $\hat{\beta}_{k}$ is the difference in hours of work between an immigrant that has been $k$ years in the US and a native-born worker.

As an alternative to Equation 1, I also estimate means for working long hours conditional on observed demographic characteristics:

$$
l h_{i t}=\alpha+\sum_{h=1}^{6} \delta_{h} C_{i t}^{h}+\sum_{k=1}^{4} \beta_{k} D_{i t}^{k}+x_{i t}^{\prime} \theta+v_{i t}
$$

where $x_{i t}$ is a vector composed of age controls (up to a quartic term), three education categories, a variable indicating whether the worker lives in a metropolitan area or not, dummy variables for whether the worker is married or has never been married, whether a worker is unionized or is covered by a union, as well as indicators for six states (California, Florida, Illinois, Texas and New York-New Jersey). In this specification I also include region fixed effects and occupation-year fixed effects. Note that any differences in the estimated coefficients of $\hat{\beta}_{k}$ between equations 1 and 2 can be attributed

\footnotetext{
${ }^{1}$ I use linear probability models instead of non-linear maximum likelihood methods, because in these latter ones there is a risk that maximum likelihood methods bias the estimates of fixed effects coefficients. For a discussion see Hsiao (1986).
} 
to the relationship between the characteristics included in vector $x_{i t}^{\prime}$ and the probability to work long hours.

I estimate equations 1 and 2 first for all workers, then for salary paid and hourly paid workers separately. The results are presented in Table 2 . The first three columns include all fulltime native and foreign-born workers, the fourth, fifth and sixth columns include all workers who are salary paid, and the last three columns include hourly paid workers only. For each group, the first column includes estimates when no demographic controls besides cohort and years in U.S. are included, the second column includes the demographic controls in the vector $x_{i t}^{\prime}$ of equation (2) and the third column includes occupation-year fixed effects ${ }^{2}$. Note that the estimates for salary paid workers change very little once demographic characteristics are added; in contrast, in the case of hourly paid workers the Years in the U.S. attenuate by almost half their magnitude.

To summarize the results in Table 2, Figure 2 shows the difference in predicted in probability of working long hours for each immigrant cohort compared to native born workers, based on the specification with all demographic controls except occupation/year fixed effects. All variables, except cohort and year in the U.S. indicators, are valued at their sample mean. The results for salary paid workers are presented in the left panel, and for hourly paid workers are presented in the right panel $^{3}$. Focusing on salary paid workers first, the results show that earlier immigrants are more likely to work long hours than more recent immigrants, and that the probability of working long hours decreases significantly after 5 years in the Unites States. After year 5 , the probability of an immigrant working long hours changes by little, and if anything it rises, although this raise is not statistically significant. These results support the hypothesis that immigrants, particularly recent ones, behave as target earners where they will work longer hours than their counterparts until they reach a determined earnings level. Whether the drop in probability after year 5 is due to changes in the sample composition (recent immigrants who work long hours return to the source countries) or

\footnotetext{
${ }^{2}$ Because the CPS occupation codes change between 2002 and 2003, I am not able to include pure occupation fixed effects. Instead, I generate a fixed effect for each 2-digit detailed occupation every year (the cross product of the occupation and year vectors).

${ }^{3}$ I exclude from the figure the predicted probability of working long hours of the earliest cohort, those who arrived after 2001, as they have been in the U.S. for less than five years and would be only a point in these figures, their probability of working long hours is $\hat{\delta}_{6}+\hat{\beta}_{1}$.
} 
due to changes in the hours of work of each worker is impossible to test with these data. In contrast to salary paid workers, the hours of work for hourly paid immigrants are not very different to those of native workers once demographic controls are added.

Note that adding a regressor for wages to equation 2 has the disadvantage that for salary paid workers the dependent variable (hours of work) is the denominator of the wage variable, this may result in the division bias discussed by Borjas (1980). To any extent, adding occupation fixed effects controls imperfectly for the worker's earnings, and when I do this, the coefficients for years in the United States and immigrant cohorts vary little. This suggests that within each occupation category, immigrants are less likely to work long hours, and this is again concentrated among salaried workers. It seems intuitive to explain the differences above of the probability of working long hours between natives and immigrants with a traditional life-cycle model (Blundell and Macurdy, 1999). This framework suggests that given a wage level, immigrant workers should be solving their utility maximizing problem in a shorter time horizon than native workers due to a positive probability of returning to the source country in the future. If this is true and for a given level of lifetime earnings, then immigrants should work longer hours than natives during their stay in the United States. While it is possible that differences in hours of work are driven by different life-cycle strategies the empirical data - presented in Table 2 even after occupation fixed effects are added - suggest that within a given occupation, and potentially similar earnings, immigrants work less hours than natives. Perhaps the main problem with explaining these differences with a traditional life-cycle model is that differences in hours of work are concentrated among salary paid workers, and the life-cycle framework fails to explain why the outcomes between hourly paid and salary paid workers differ.

\section{Differences Due to Occupation and Industry Distribution}

The previous section shows that differences in the probability of working long hours persist after controlling for demographic characteristics, and even within occupations once year/occupation fixed effects are added. Next I explore whether these differences are explained with differences in the distribution of workers across occupations. I use detailed three-digit occupation codes and perform 
the following counterfactual exercise ${ }^{4}$ :

$$
l h_{i}^{j k}=\sum_{i=1}^{I} \theta_{i}^{j} \times l h_{i}^{k}
$$

where $\theta_{i}^{j}$ is the proportion of workers in group $j$ that work in occupation $i\left(\sum \theta_{i}^{j}=1\right)$; also, let $l h_{i}^{k}$ be the proportion of workers from group $k$ that work long hours in occupation $i$ (where $k, j \in$ natives, immigrants); then the proportion working 50 or more hours in occupation $i$ from group $k$ if they have the same occupation distribution of group $j$, will be $\theta_{i}^{j} \times l h_{i}^{k}$. Summing across all occupations gives the probability that workers in group $k$ work long hours if they have the same distribution as group $j$ which is $l h_{i}^{j k}$.

I calculate these counterfactuals for 3-digit occupation and industry codes, and the results are presented in Table 3. Note that in this sample the overall difference in probability of working long hours between natives and immigrants is 7 percentage points. The results in Table 3 indicate that if salaried immigrant workers have the same occupation mix as natives, the long hours gap would increase to 8 percentage points. This suggests that changing the occupation distribution of immigrants to that of natives will have little impact on the hours of work of the foreign-born, and if any, it will increase this gap slightly. A similar exercise shows that differences in industry mix explain none of the differences between native and immigrant workers. Note that in this sample the overall difference in probability of working long hours between native and immigrants is 7 percentage points. The results in Table 3 indicate that if salaried immigrant workers had the same occupation mix as natives, the long hours gap would increase to 8 percentage points. This suggests that changing the occupation distribution of immigrants to that of natives will have little impact on the hours of work of the foreign-born, and if any, it will increase slightly this gap. A similar exercise shows that differences in industry mix explain none of the differences between native and immigrant workers.

\footnotetext{
${ }^{4}$ To keep occupation and industries consistent, in here I use the 1994-2002 CPS ORG sample. Starting in 2003 the occupation and industry classification is not consistent with those in previous surveys. Further, I restrict my sample to occupations with at least 25 immigrant workers. Note that the predicted means in this exercise will be different to those in table 1 , because the samples are different.
} 


\section{Differences Across Occupations in Incentives to Supply Long Hours}

If differences in occupation distribution fail to explain the differences in the workweek of salary paid native and immigrant workers, next I explore the extent to which these differences lie in the characteristics of each occupation. In particular I analyze whether differences in the dispersion of earnings predicts different hours of work between immigrant and native workers. I follow Bell and Freeman (2001a, 2001b) who argue that greater within occupation earnings dispersion incentivizes the worker to supply longer weekly hours, as long workweeks are associated with greater future rewards - perhaps though a promotion, increases in earnings, or even a lower probability of being laid off. Heuristically, this can be thought of as a tournament (Lazear and Rosen, 1981) where the winner receives a higher payoff, and to the extent that working long hours is related to the probability of winning the tournament, workers will have a stronger incentive to supply that extra hour of work. Here, I use two metrics to estimate the within occupation dispersion of earnings: first, as Bell and Freeman (2001a, 2001b) do the within occupation standard deviation of weekly earnings; second, following Kuhn and Lozano (2008) the gap in the within-occupation 90th and 10th percentile earners. More formally, the linear probability model estimated in this section is ${ }^{5}$ :

$$
l h_{i j t}=\alpha+\sum_{k=1}^{4} \beta_{k} D_{i j t}^{k}+\sum_{k=0}^{4} \gamma_{k} D_{i t}^{k} \times S_{j t}+\sum_{h=1}^{6} \delta_{h} C_{i j t}^{h}+\psi E_{j t}+x_{i t}^{\prime} \theta+v_{i j t}
$$

where $\gamma_{k}$ estimates the association between the probability of working long hours for each years in the U.S. group (where $k=0$ are U.S. born natives) and the within occupation distribution of income. The variable $l h_{i j t}$ takes a value of one if the workweek is 50 hours or longer, zero otherwise; $E_{j t}$ represents the occupation/year average

$$
\ln
$$

weekly earnings, the variable $S_{j t}$ represents the occupation/year standard deviation or 90-10 earnings difference; the vector $x_{i t}^{\prime}$ includes all demographic variables as in equation 2. Again, I estimate equation 4 for salary paid and hourly paid workers separately. Note that the above specification

\footnotetext{
${ }^{5}$ To take advantage of the complete sample I use the occupation-year cross product. The results are robust if I use the sample between 1994-2002 and use pooled occupation categories instead
} 
allows for the occupation level of earnings to vary across different years in the U.S. category ${ }^{6}$.

Estimates of equation 4 are presented in Table 4. The first column presents estimates for salary paid workers when the occupation earnings dispersion is measured with the standard deviation of $l n$ weekly earnings. The second column presents estimates for salary paid workers when the dispersion of earnings is measured with the difference in earnings between the 90th percentile and the 10th percentile. The third and fourth column replicates the exercise for hourly paid workers. Two differences in the estimates between hourly paid and salaried workers are worth noting: first, while the interaction estimates for salary paid workers are positive and significant, the estimates for hourly paid are negative; second, the magnitude of the intercepts for each year in the U.S. category for salary paid is negative, and for hourly paid is positive and greatest for the most recent immigrants.

To understand the magnitude of these estimates, Table 5 presents the predicted incidence of working long hours for salary paid and hourly paid workers, evaluated at different percentiles in the across occupations' earnings distribution (all other variables are evaluated at sample means). The results show that among salary paid workers employed in occupations where earnings dispersion is compact (at the 10th percentile) native workers have a predicted probability of working long hours of $28.5 \%$; immigrants who have been in the U.S. between $0-5$ years have a probability of working long hours of $20 \%$; those who have been in the U.S. for $6-10$ years have a probability of $17.2 \%$; those who have been in the U.S. between 11-20 years have a probability of $17.5 \%$; while the earliest immigrants have a probability of working long hours of $19 \%$. The estimates for hourly paid workers are: natives $10 \%$, recent immigrants $10 \%$ and this probability monotonically decreases to $8 \%$ for the earliest immigrants. Importantly, note that as the occupation dispersion of earnings increases, so will the the propensity of working long hours for all salary paid workers, not so for hourly paid.

Analyzing changes across the table towards occupations with greater earnings dispersion increases the probability of working long hours for salary paid workers, and while absolute changes between natives and immigrants are similar, the relative differences between nativity groups do decrease. For example while an immigrant worker who has been in the U.S for less than five years and works in an

\footnotetext{
${ }^{6} \mathrm{As}$ in the previous section I drop observations in which each occupation/year has less than 25 immigrant observations, and to control for outliers I further drop from the sample observations supplying more than 80 hours of work in their main job.
} 
occupation in the 10th percentile of the dispersion distribution is $30 \%$ less likely to work long hours than a native born worker, a similar immigrant working in an occupation in the 90th percentile is $20 \%$ less likely to work long hours than a native born worker. In contrast, moving to a higher dispersion occupation changes little the long hours incidence for hourly paid workers.

I readily admit that it is quite possible that immigrants who have a stronger preference for long workweeks, stronger drive, or smaller cost of effort are more likely to sort themselves into high earnings dispersion occupations, and the relative reduction in differences between immigrants' and natives' hours may be due to this sorting. While I can't argue that these results are causal, I do see a strong positive association between hours and the occupations' earnings distribution. These results are also consistent with the hypothesis that recent immigrants behave as target earners, who tend to supply very long hours until they reach a desired level of earnings. This differs with immigrants who have been in the U.S. for more than five years, where there is little variation in the propensity of working long hours and rise slightly over the rest of the worker's life cycle. Estimates using the 90-10 earnings gap as measure of earnings dispersion are similar. Yet, the reversal of signs between hourly paid workers and salary paid workers suggest that these workers face very different labor market incentives. Still, and because nativity differences in the probability of working long hours among hourly paid workers are very small, I leave this question as topic of future research and in what follows concentrate on differences among salary paid workers.

\section{Aggregated Analysis on Differences due to Occupation Characteristics}

The results in section 3 suggested that even after controlling for demographic characteristics, and as well as controlling for occupation-year heterogeneity, differences in the incidence of long hours of work still persist. Further, the analysis in section 4 shows that these differences are not due to different distributions across occupations. Yet, the results in the last section suggest that greater within occupation earnings dispersion is positively associated with a worker's propensity to work long hours, and that differences in long hours between natives and immigrants decrease as the occupation's dispersion of earnings widens. In this section, I aggregate the data into each occupation/year to 
further explore which occupation's characteristics are associated more strongly with immigrantnatives differences of hours of work.

The following exercise consist in analyzing the association between immigrant-native differences in hours of work and ten different occupation characteristics. The first four occupation characteristics are traditionally associated with labor supply studies and refer to the first moment of the within occupation earnings distribution: these are $\ln$ weekly earnings, $\ln$ hourly wage, the immigrantnative differences in $l n$ weekly earnings, and the immigrant-native differences in $l n$ hourly wages. The second set of variables, following Kuhn and Lozano (2008), define the long hours premium as a very crude approximations of the contemporaneous returns to working long hours. In particular, I estimate a linear long hours premium which is the coefficient $\beta_{1}$ when estimating the following regression for each occupation/year category separately (400 times, one for each occupation $J$ and year $T$ combination):

$$
E_{i J T}=\beta_{0}+\beta_{1} H_{i J T}+x_{i J T}^{\prime}+\epsilon_{i J T}
$$

where $E_{i J t}$ is the natural $\log$ of weekly earnings for worker $i$ in year $T$ and occupation $J, H_{i J T}$ is that worker's usual hours of work in the main job, and $x_{i J T}^{\prime}$ is a vector including age, age squared, age cube and age quartic, education dummies, regional variables, marital status, metropolitan status and union status. Again, I recover $\hat{\beta}_{1}$ for each occupation and define it as a linear long hours premium. Alternatively, I estimate a quartic long hours premium which is the difference for each occupation/year category of the predicted $\ln$ weekly earnings estimates at 40 hours and at 55 hours from the following regression:

$$
E_{i J T}=\beta_{0}+\beta_{1} H_{i J T}+\beta_{2} H_{i J T}^{2}+\beta_{3} H_{i J T}^{3}+\beta_{4} H_{i J T}^{4}+x_{i J T}^{\prime}+v_{i J T}
$$

whose elements are defined as in equation 5 above, but has up to a quartic term of usual hours in the main job. Again, I estimate equation 6 separately for each occupation/year category. The last four occupation characteristics, also borrowed from Kuhn and Lozano (2008), estimate the dispersion of 
earnings across occupations: the first one is the standard deviation of $l n$ weekly earnings, the second one is the 90-10 Gap of weekly earnings, the third one is the standard deviation of the residuals from equation 6 , and the last one is the 90-10 Gap of the residuals from equation 6 .

To understand the role that occupation characteristics play on the hours of work of immigrant workers, I regress the difference in long hours between natives and immigrants on each of the above ten characteristics. Each regression is further estimated using year fixed effects, and weighting each cell by its number of observations. The results of these regressions are presented in Table 7 . The first column includes all immigrants in each occupation/year, and the second and third column partitions the sample into recent immigrants who have spent 0-10 years in the United States, and earlier immigrants who have spent $11+$ years in the U.S. The results for the first two rows in Table 7 show that the occupation's level of $l n$ weekly earnings and $l n$ hourly wages have no relationship with native-immigrant differences in the probability of working long hours, but the third and fourth rows do show that earnings differences between native-immigrant are positively associated with the difference in probability of working long hours. This result is not surprising and it suggests positive elasticities of labor supply. That is, immigrants supply shorter hours of work than natives in the same occupation because they have lower earnings, and hence a lower opportunity cost of leisure (of course as long as leisure is a normal good).

The second panel in Table 6 tests whether two measures that proxy for the returns to working long hours are associated with greater immigrant-native incidence of long work weeks. The first one, the coefficient of weekly earnings on usual hours of work from equation 5 , shows no association between the long hours premium and long hours differences. The same is true - no association with long hours differences - when I use the quartic hours specification in equation 6 and compare earnings of workers at 40 usual weekly hours versus earnings of workers at 55 usual weekly hours. The bottom panel, shows four different measures of within occupation earnings dispersion, note that all coefficients are positive, and all but three are statistically significant different to zero at the 95\% confidence level. That is, the results in this panel show that within occupation distribution of earnings are positively associated with immigrant-natives differences in the probability of working 
more than 50 hours. Importantly, the positive estimates of the coefficients of the standard deviation of $l n$ earnings, and the 90-10 Gap of $l n$ earnings are consistent with the estimates from Table 4 and Table 5. Further, it is worth noting that the magnitude of the estimates in the last two measures (standard deviation of residuals and 90-10 residual gap) are almost twice as big as the magnitude of the first two measures (standard deviation of $l n$ earnings and 90-10 $l n$ earnings gap). This is important because the residual measures reflect the within occupation distribution net of very detailed demographic and hours controls.

Finally, I estimate regressions of occupation differences in long workweeks on a measure of the first moment of the earnings distribution (native-immgrants $l n$ earnings difference) and a second moment of the earnings distribution or the long hours premium. Again, each observation represents an occupation/year category, each regression includes year fixed effects and is weighted by the cell's number of observations. The first two rows regress long hours differences on $l n$ earnings differences and the within occupation long hours earnings premium. Note that the coefficient for $l n$ earnings differences remains positive and statistically significant, but the coefficient for the long hours premium is now negative and statistically significant different from zero. This result suggests that once one controls for an immigrant earnings level relative to natives, immigrants are more likely to have a positive association between the probability of working long hours and the contemporaneous premium from working long hours. This is true regardless of which long hours premium measure I use, and suggests that more immigrants would be willing to work long hours than natives, holding constant their earnings level and return to working those long hours.

The next two panels show estimates of differences in the workweek's length regressed on difference in $l n$ earnings and the standard deviation of $l n$ earnings (or the 90-10 $l n$ earnings gap). Once earnings differences are added, the coefficients for these two dispersion measures attenuate towards zero, and neither is statistically significant greater than zero. Importantly, the coefficient for difference in $l n$ weekly earnings remains positive and statistically significant different than zero. The last two panels show regressions of differences in long workweeks on earnings differences and the residuals dispersion estimates from equation 6 . When my explanatory variables are $\ln$ earnings 
differences and the standard deviation of the $l n$ earnings residuals, the coefficient for the dispersion measures decreases in magnitude as well, yet is still statistically significant when all immigrants are included. When the measure is the 90-10 Residuals Gap, the coefficient remains positive in all cases, and statistically significant greater than zero in the case of all immigrants or in the case of earlier immigrants. Importantly, these results suggest that differences in hours of work are not only associated with differences in native-immgrant earnings level, but also that differences in hours of work are associated with the within occupation earnings dispersion - especially once that observed hours of work and demographic characteristics are netted out. Further, and to the extent that these dispersion measures are appropriate proxies for the future rewards to the worker from working long hours (future earnings growth or promotions represented with wider distributions of earnings), the within occupation incentives to supply long hours for immigrants are attenuated relative to natives'. If in contrast one focuses on contemporaneous returns to working long hours - the long hours premium - then the association between these incentives and native-immigrant differences in the probability of working long hours is negative. That is, increases in the contemporaneous rewards such as the long hours premium decrease the differences in the probability to work long hours.

\section{Discussion}

The results in the previous section show that occupation characteristics are important determinants of the differences in the length of the workweek between immigrants and natives. Two factors that reduce the hours of work by immigrants are lower earnings compared to native workers within the same occupation, and the dispersion of earnings within each occupation. This second metric is important, as it is an approximation of the expected change in earnings of a worker's lifetime income path. Importantly, if an immigrant salary paid worker perceives a positive probability of future separation from his job then these incentives will diminish. These two measures are not intended to be silver bullets that will completely explain all of the differences, but rather to bring attention to the importance of occupation characteristics on an immigrant labor supply time allocation problem.

I have paid little attention to any demand side differences explaining this gap. It may be that 
this gap is a consequence of three demand-side phenomena: the first one is that foreign-born workers are less likely to work long hours than US born natives because immigrants labor supply is more sensitive to weak labor market conditions. This seems plausible for hourly paid workers but not for salaried workers particularly full-time salaried workers- since arguably these workers have more discretion over the amount of hours they choose to work. Also any effects from weak labor market conditions will be reflected in labor force participation or employment (extensive margin), not weekly hours of work (intensive margin). A similar argument is that immigrants supply less hours of work because of unobserved non-market mechanisms like discrimination. If this is true, it strikes me that discrimination will also have an effect on the hiring decision of a salaried worker, not on the decision to demand long hours of work from him or not.

It may also be that immigrants work shorter hours than natives because they are constrained in the number of hours they can work (Altonji and Paxson, 1988). Assume that each job is associated with a given number of hours and weekly earnings, and due to search costs and labor market frictions, an immigrant worker is not able to find a job that maximizes his utility on desired hours and earnings that is, he is not over his labor supply curve. Assume that a worker is supplying less hours of work than he wishes to, then this worker will be underemployed, which could result in the worker being: 1) more likely to switch jobs seeking to find one where he maximizes his utility with desired hours/earnings; and 2) more likely to work shorter hours in the old job relative to the new job. I cannot distinguish in the data the explanation from the previous section that attributes differences in the probability of working long hours to to occupation characteristics from the fact that immigrant workers are potentially underemployed. Quite possibly these two explanations occur simultaneously in some cases.

\section{Conclusion}

In this paper I document the differences of hours worked by foreign-born and native-born workers. Analyzing the hours of work of immigrants is interesting as it potentially represents the effort and dedication that a worker invests in his job. Equally important, hours of work are associated with 
higher future earnings and promotions. I concentrate my analysis on a particular measure of labor supply: the upper tail of the distribution of hours worked, represented by workers supplying 50 or more weekly hours. I find that immigrants are less likely to work long hours than natives, and that these differences are surprisingly greatest among salaried, college graduates or high-income workers.

I explain differences in the propensity to work long hours using two within occupation measures: first, immigrants tend to work shorter hours than natives in occupations where native-immigrant earnings differences are big. Second, immigrants also tend to work shorter weekly hours in occupations where the residual wage inequality is wide. This second measure is important as it has been argued to be a good proxy for potential future earnings growth, and the wider the occupation's earnings distribution, the greater the incentives to supply long hours of work. These results imply that if an immigrant worker perceives a positive probability of separating from his job due to return migration or further migration, then these incentives to work long weekly hours will attenuate.

This paper also highlights the importance that incentives play on an immigrant worker's investments in host country specific capital. In particular, attenuating the incentives to work long hours due to a positive probability of future migration, generates a moral hazard where shorter hours will result in lower earnings growth for the worker and a smaller probability of future promotions. This, in turn, will flatten an immigrant worker's assimilation earnings profile. Not only will this have negative repercussions on the economic well-being of the worker and his family, but of the U.S. economy as a whole given that foreign born workers constitute now such an important portion of America's labor force. 


\section{References}

Altonji, Joseph G. and Christina H. Paxson (1988). Labor Supply Preferences, Hours Constraints and Hours-Wage Trade Offs Journal of Labor Economics Vol 6 No 2 (April 1988) pp. 254-276.

Baker, M. and D. Benjamin (1997), "The Role of the Family in Immigrants" Labor Market Activity: An Evaluation of Alternative Explanations", American Economic Review 87 (September 1997): 705727

Bell, Linda and Richard Freeman (2001a). The Incentive for Working Hard: Explaining Hours Worked Differences in the US and Germany Labour Economics 8 (2) (May 2001). 181-202.

Bell, Linda and Richard Freeman. (2001b) Working Hard. in Ging Wong and Garnett Picot, eds. Working Time in Comparative Perspective (vol. 1). Kalamazoo, Mich.: W. E. Upjohn Institute for Employment Research, 2001.

Blau Francine D., Lawrence M. Kahn, (2005) Gender and Assimilation Among Mexican Americans NBER Working Paper 11512 (June 2005)

Blundell, Richard and Thomas Macurdy (1999) Labor Supply: A review of Alternative Approaches in Orley Ashenfelter and David Card Editors Handbook of Labor Economics 3A, Elseiver.

Borjas, George J. (1980) The Relationship Between Wages and Weekly Hours of Work: The Role of Division Bias, Journal of Human Resources, Volume15(3), Summer 1980, pp. 409-423.

Borjas, George J. (1982) The Earnings of Male Hispanic Immigrants in the United States Industrial and Labor Relations Review Vol 35(3) April 1982 pp. 343-353.

Borjas, George J. (1995) Assimilation and Changes in Cohort Quality Revisited: What Happened to Immigrant Earnings in the 1980s? Journal of Labor Economics 13, no. 2 (April 1995):pp. 201-245.

Borjas, George J. and Brent Bratsberg (1996). Who Leaves? The Outmigration of Foreign-born The Review of Economic and Statistics Volume 78, No. 1 (Feb, 1996) pp. 165-176.

Bratti, Massimilano and Sefano Staffolani (2007), Effort-based Career Opportunities and Working Time. International Journal of Manpower Vol 28(6) pp. 489-512.

Chiswick, B., "The Effect of Americanization on the Earnings of Foreign Born Men", Journal of Political Economy 86 (1978): 897-921.

Coleman, Mary T. and John. Pencavel. (1993) Changes in Work Hours of Male Employees, 19401988. Industrial and Labor Relations Review 46(2) (January 1993): 262-283.

Cortes, Kelena (2004) Are Refugees Different from Economic Immigrants? Some Empirical Evidence on the Heterogeneity of Immigrant Groups in the United States The Review of Economics and Statistics May 2004, 86(2) pp. 465-480. 
DeConto, Jesse James Americas Criminal Immigration Policy, How US law punishes hard work Reason Magazine February, 2006.

DaVanzo, Julie (1983) Repeat Migration in the United States: Who Moves Back and Who Moves On Review of Economics and Statistics, Volume 65, No. 4 (November, 1983).

Dustmann, Christian (1993) Earnings Adjustments of Temporary Migrants Journal of Population Economics, Volume 6, pp. 153168.

Dustmann, Christian (2003) Return migration, wage differentials, and the optimal migration duration European Economic Review, Volume 47, Issue 2 (April 2003).

Fama, Eugene F. (1991) Time, Salary, and Incentive Payoffs in labor Contracts Journal of Labor Economics Vol. 9 No. 1 (January 1991) pp. 25-44.

Fehr, Ernst, Erich Kirchler, Andreas Weichbold, Simon Gchter. When Social Norms Overpower Competition: Gift Exchange in Experimental Labor Markets, Journal of Labor Economics, 1998, vol. 16 , no. 2

Hamermesh, Daniel S. (2002) 12 Million Salaried Workers Missing Industrial and Labor Relations Review Vol55(4) (July, 2002) pp. 549-666.

Hsiao, Cheng (1986) Analysis of Panel Data. Econometric Society Monographs No. 11. Cambridge University Press.

Susan Johnson and Peter Kuhn (2004). Increasing Male Earnings Inequality in canada and the United States, 1981-1997: The Role of Hours Changes versus Wage Changes. Canadian Public Policy / Analyse de Politiques, Vol 20(2) pp.155-175.

Kuhn, Peter J., and Fernando A Lozano (2008), The Expanding Workweek? Understanding Trends in Long Work Hours Among US Men, 1979-2006 Journal of Labor Economics Vol 26(2) (April 2008) pp 311-344.

Lazear, Edward and Sherwin Rosen (1981) Rank Order Tournaments as Optimal Contracts Journal of Political Economy Vol 88(5), pp. 841-864.

Lubotsky, Darren (2007) Chutes or Ladders? A Longitudinal Analysis of Immigrant Earnings Journal of Political Economy Vol 115(5) pp. 820-867.

Porter, Eduardo, Here Illegally, Working Hard and Paying Taxes The New York Times Business Section June 19, 2006 
Table 1. Sample Proportions and Proportion Working Long Hours

\begin{tabular}{lcccc}
\hline \hline & $(1)$ & $(2)$ & $(3)$ & $(4)$ \\
& U.S. & Foreign & U.S. & Foreign \\
& Natives & Born & Natives & Born \\
& Proportion Sample & Proportion Long Hours \\
\hline Employed & \multicolumn{2}{c}{ Among all not self-employed men } \\
\hline Fulltime Employed (29+ Hrs) & 0.936 & 0.932 & 0.209 & 0.125 \\
& $(0.000)$ & $(0.001)$ & $(0.000)$ & $(0.001)$ \\
Observations & 0.850 & 0.847 & 0.215 & 0.129 \\
& $(0.000)$ & $(0.001)$ & $(0.000)$ & $(0.001)$ \\
Hourly Paid & \multicolumn{2}{c}{842,639} & \multicolumn{2}{c}{99,953} \\
Salaried Paid & 0.516 & 0.605 & 0.105 & 0.066 \\
Union Member & $(0.001)$ & $(0.002)$ & $(0.001)$ & $(0.001)$ \\
Age 25-34 & 0.484 & 0.395 & 0.333 & 0.226 \\
& $(0.001)$ & $(0.002)$ & $(0.001)$ & $(0.002)$ \\
Age 35-44 & 0.203 & 0.123 & 0.132 & 0.070 \\
& $(0.000)$ & $(0.001)$ & $(0.001)$ & $(0.002)$ \\
Age 45-54 & 0.297 & 0.332 & 0.203 & 0.121 \\
& $(0.001)$ & $(0.002)$ & $(0.001)$ & $(0.002)$ \\
Age 55-64 & 0.323 & 0.337 & 0.229 & 0.140 \\
High School Dropout & $(0.001)$ & $(0.002)$ & $(0.001)$ & $(0.002)$ \\
High School Graduate & 0.262 & 0.223 & 0.221 & 0.129 \\
Some College & $(0.001)$ & $(0.001)$ & $(0.001)$ & $(0.002)$ \\
College Graduate & 0.118 & 0.108 & 0.196 & 0.118 \\
& $(0.000)$ & $(0.001)$ & $(0.001)$ & $(0.003)$ \\
& 0.072 & 0.348 & 0.132 & 0.083 \\
& $(0.000)$ & $(0.002)$ & $(0.002)$ & $(0.002)$ \\
& 0.330 & 0.228 & 0.156 & 0.103 \\
& $(0.001)$ & $(0.001)$ & $(0.001)$ & $(0.002)$ \\
& 0.283 & 0.133 & 0.192 & 0.121 \\
& $(0.001)$ & $(0.001)$ & $(0.001)$ & $(0.003)$ \\
& 0.314 & 0.291 & 0.318 & 0.207 \\
& $(0.001)$ & $(0.002)$ & $(0.001)$ & $(0.003)$ \\
& 713,961 & 84,607 & 713,961 & 84,607 \\
\hline \hline
\end{tabular}

Sample: All not self-employed men in the CPS ORG age 25-64 (1994-2006) 
Table 2. Linear Probability Model including Cohort and U.S. Experience Controls

\begin{tabular}{|c|c|c|c|c|c|c|c|c|c|}
\hline & (1) & (2) & (3) & (4) & $(5)$ & (6) & (7) & (8) & (9) \\
\hline & \multicolumn{3}{|c|}{ All Workers } & \multicolumn{3}{|c|}{ Salary Paid Workers } & \multicolumn{3}{|c|}{ Hourly Paid Workers } \\
\hline \multirow[t]{2}{*}{ Arrived 1960-1969 } & -0.005 & 0.000 & 0.000 & 0.005 & 0.016 & 0.017 & -0.008 & $-0.011 *$ & $-0.011 *$ \\
\hline & $(0.005)$ & $(0.005)$ & $(0.005)$ & $(0.009)$ & $(0.010)$ & $(0.010)$ & $(0.005)$ & $(0.005)$ & $(0.005)$ \\
\hline \multirow{2}{*}{ Arrived 1970-1979 } & $-0.011 *$ & 0.000 & -0.002 & -0.002 & 0.022 & $0.026^{*}$ & $-0.014^{*}$ & $-0.017^{*}$ & $-0.018^{*}$ \\
\hline & $(0.006)$ & $(0.006)$ & $(0.006)$ & $(0.011)$ & $(0.012)$ & $(0.012)$ & $(0.005)$ & $(0.006)$ & $(0.006)$ \\
\hline \multirow[t]{2}{*}{ Arrived 1980-1989 } & $-0.024 *$ & -0.011 & $-0.016^{*}$ & -0.016 & 0.005 & 0.008 & $-0.027 *$ & $-0.027 *$ & $-0.031 *$ \\
\hline & $(0.007)$ & $(0.007)$ & $(0.007)$ & $(0.013)$ & $(0.014)$ & $(0.014)$ & $(0.006)$ & $(0.007)$ & $(0.007)$ \\
\hline \multirow[t]{2}{*}{ Arrived 1990-1996 } & $-0.048 *$ & $-0.028^{*}$ & $-0.029 *$ & $-0.053^{*}$ & -0.024 & -0.007 & $-0.036 *$ & $-0.036^{*}$ & $-0.043 *$ \\
\hline & $(0.008)$ & $(0.008)$ & $(0.008)$ & $(0.015)$ & $(0.016)$ & $(0.016)$ & $(0.007)$ & $(0.008)$ & $(0.008)$ \\
\hline \multirow[t]{2}{*}{ Arrived 1997-2006 } & $-0.072 *$ & $-0.035^{*}$ & $-0.040 *$ & $-0.083^{*}$ & $-0.042 *$ & -0.032 & $-0.046^{*}$ & $-0.040^{*}$ & $-0.049 *$ \\
\hline & $(0.009)$ & $(0.009)$ & $(0.009)$ & $(0.016)$ & $(0.018)$ & $(0.018)$ & $(0.008)$ & $(0.010)$ & $(0.009)$ \\
\hline \multirow[t]{2}{*}{$0-5$ Years in US } & $-0.031 *$ & $-0.037 *$ & $-0.019 *$ & $-0.039 *$ & $-0.072 *$ & $-0.055^{*}$ & -0.004 & -0.001 & 0.013 \\
\hline & $(0.008)$ & $(0.008)$ & $(0.008)$ & $(0.014)$ & $(0.016)$ & $(0.016)$ & $(0.007)$ & $(0.008)$ & $(0.008)$ \\
\hline \multirow[t]{2}{*}{$6-10$ Years in US } & $-0.070 *$ & $-0.063^{*}$ & $-0.047 *$ & $-0.097 *$ & $-0.123^{*}$ & $-0.104 *$ & $-0.020 *$ & $-0.015^{*}$ & -0.005 \\
\hline & $(0.006)$ & $(0.007)$ & $(0.007)$ & $(0.012)$ & $(0.014)$ & $(0.014)$ & $(0.006)$ & $(0.007)$ & $(0.007)$ \\
\hline \multirow[t]{2}{*}{$11-20$ Years in US } & $-0.077^{*}$ & $-0.068^{*}$ & $-0.056^{*}$ & $-0.101^{*}$ & $-0.120^{*}$ & $-0.104 *$ & $-0.031 *$ & $-0.024 *$ & $-0.017 *$ \\
\hline & $(0.005)$ & $(0.005)$ & $(0.005)$ & $(0.010)$ & $(0.010)$ & $(0.010)$ & $(0.005)$ & $(0.005)$ & $(0.005)$ \\
\hline \multirow[t]{2}{*}{$20+$ Years in US } & $-0.083^{*}$ & $-0.062 *$ & $-0.051 *$ & $-0.110^{*}$ & $-0.100^{*}$ & $-0.082 *$ & $-0.043^{*}$ & $-0.027 *$ & $-0.022 *$ \\
\hline & $(0.003)$ & $(0.003)$ & $(0.003)$ & $(0.005)$ & $(0.006)$ & $(0.005)$ & $(0.003)$ & $(0.003)$ & $(0.003)$ \\
\hline \multirow[t]{2}{*}{ Constant } & $0.218^{*}$ & $-0.873^{*}$ & $-0.810^{*}$ & $0.336^{*}$ & $-1.394^{*}$ & $-1.180 *$ & $0.108^{*}$ & $-0.569 *$ & $-0.522 *$ \\
\hline & $(0.001)$ & $(0.141)$ & $(0.138)$ & $(0.001)$ & $(0.260)$ & $(0.254)$ & $(0.001)$ & $(0.148)$ & $(0.147)$ \\
\hline Demographic Controls & No & Yes & Yes & No & Yes & Yes & No & Yes & Yes \\
\hline Occ-Year Fixed Effects & No & No & Yes & No & No & Yes & No & No & Yes \\
\hline R-squared & 0.004 & 0.091 & 0.129 & 0.004 & 0.029 & 0.090 & 0.002 & 0.008 & 0.025 \\
\hline $\mathrm{N}$ & & 798,568 & & & 377,452 & & & 421,116 & \\
\hline
\end{tabular}

* Denotes statistically significant at 5\% significance level. Sample: All fulltime working men age 25-64 in the 1994-2006 CPS ORG.

Demographic controls include married status, age, age squared, age cubic, age quartic, education indicators (high school graduates, some college, college graduates), year and region fixed effects, controls for living in California, Texas, Illinois, Florida and New-York-New Jersey, indicators for salary paid, metropolitan status and union membership. 
Table 3. Detailed 3-Digit Occupation and Industry Counterfactuals

\begin{tabular}{|c|c|c|c|c|c|}
\hline & (1) & (2) & (3) & (4) & (5) \\
\hline $\begin{array}{r}\text { Distribution: } \\
\text { Means: }\end{array}$ & $\begin{array}{l}\text { U.S. Native } \\
\text { U.S. native }\end{array}$ & $\begin{array}{l}\text { Foreign Born } \\
\text { Foreign Born }\end{array}$ & $\begin{array}{c}\text { U.S. Native } \\
\text { Foreign Born }\end{array}$ & $\begin{array}{c}\text { Foreign Born } \\
\text { U.S. Native }\end{array}$ & Cell Count \\
\hline \multicolumn{6}{|c|}{ A) All Workers } \\
\hline 3-Digit Occupation & 0.202 & 0.139 & 0.139 & 0.177 & 241 \\
\hline 3-Digit Industry & 0.211 & 0.139 & 0.130 & 0.223 & 186 \\
\hline \multicolumn{6}{|c|}{ B) Salary Paid } \\
\hline 3-Digit Occupation & 0.302 & 0.246 & 0.224 & 0.321 & 147 \\
\hline 3-Digit Industry & 0.307 & 0.243 & 0.199 & 0.363 & 130 \\
\hline \multicolumn{6}{|c|}{ C) Hourly Paid } \\
\hline 3-Digit Occupation & 0.086 & 0.071 & 0.063 & 0.088 & 162 \\
\hline 3-Digit Industry & 0.100 & 0.072 & 0.062 & 0.105 & 156 \\
\hline
\end{tabular}

Sample: All salary and hourly paid, full time, not self employed men age 25-64 in the CPS ORG 1994-2002. observations are restricted to occupations with at least 25 immigrant workers or industries with at least 25 immigrant workers. 
Table 4. OLS Regression including Occupation Wages and Dispersion Measures

\begin{tabular}{|c|c|c|c|c|}
\hline \multirow{3}{*}{$\begin{array}{l}\text { Dependent Variable P(Long Hours })=1 \\
\text { Dispersion Measure ln Earnings }\end{array}$} & (1) & $(2)$ & (3) & (4) \\
\hline & \multicolumn{2}{|c|}{ Salaried Paid } & \multicolumn{2}{|c|}{ Hourly Paid } \\
\hline & $\begin{array}{c}\text { Std } \\
\text { Deviation }\end{array}$ & $\begin{array}{c}90-10 \\
\text { Difference }\end{array}$ & $\begin{array}{c}\text { Std } \\
\text { Deviation }\end{array}$ & $\begin{array}{c}90-10 \\
\text { Difference }\end{array}$ \\
\hline \multirow[t]{2}{*}{$0-5$ Years } & $-0.098 *$ & $-0.112 *$ & $0.096 *$ & $0.164 *$ \\
\hline & $(0.037)$ & $(0.044)$ & $(0.042)$ & $(0.038)$ \\
\hline \multirow[t]{2}{*}{ 5-10 Years } & -0.052 & $-0.051 *$ & 0.057 & $0.106 *$ \\
\hline & $(0.034)$ & $(0.042)$ & $(0.040)$ & $(0.038)$ \\
\hline \multirow[t]{2}{*}{$11-20$ Years } & $-0.067 *$ & $-0.025^{*}$ & 0.056 & $0.104 *$ \\
\hline & $(0.029)$ & $(0.036)$ & $(0.031)$ & $(0.032)$ \\
\hline \multirow[t]{2}{*}{$20+$ Years } & $-0.092 *$ & $-0.111^{*}$ & 0.053 & $0.110 *$ \\
\hline & $(0.032)$ & $(0.038)$ & $(0.037)$ & $(0.036)$ \\
\hline \multirow[t]{2}{*}{ Natives X Occ Earnings Dispersion } & $0.561 *$ & $0.456 *$ & 0.025 & $0.057 *$ \\
\hline & $(0.014)$ & $(0.006)$ & $(0.018)$ & $(0.007)$ \\
\hline \multirow[t]{2}{*}{ 0-5 Yrs X Occ Earnings Dispersion } & $0.596^{*}$ & $0.492 *$ & $-0.202 *$ & $-0.096^{*}$ \\
\hline & $(0.062)$ & $(0.034)$ & $(0.096)$ & $(0.035)$ \\
\hline \multirow[t]{2}{*}{ 6-10 Yrs X Occ Earnings Dispersion } & $0.426^{*}$ & $0.404 *$ & -0.141 & -0.054 \\
\hline & $(0.057)$ & $(0.033)$ & $(0.090)$ & $(0.035)$ \\
\hline \multirow[t]{2}{*}{ 11-20 Yrs X Occ Earnings Dispersion } & $0.467 *$ & $0.387 *$ & $-0.157 *$ & $-0.062 *$ \\
\hline & $(0.050)$ & $(0.028)$ & $(0.069)$ & $(0.029)$ \\
\hline \multirow[t]{2}{*}{ 20+ Yrs X Occ Earnings Dispersion } & $0.554 *$ & $0.475^{*}$ & $-0.156^{*}$ & $-0.070^{*}$ \\
\hline & $(0.057)$ & $(0.031)$ & $(0.083)$ & $(0.034)$ \\
\hline \multirow[t]{2}{*}{ Constant } & -1.790 & -2.012 & -0.663 & -0.693 \\
\hline & $(0.264)$ & $(0.262)$ & $(0.149)$ & $(0.149)$ \\
\hline R-Squared & 0.035 & 0.049 & 0.009 & 0.009 \\
\hline $\mathrm{N}$ & 363,858 & 363,858 & 415,181 & 415,181 \\
\hline
\end{tabular}

* Denotes statistically significant at 5\% significance level. Sample: All salary and hourly paid, full time, not self employed men age 25-64 in the CPS ORG 1994-2006, observations are restricted to occupations-years with at least 25 immigrant workers. Variables omitted from estimation are average cohort dummy variables, occupation earnings, age, age squared, cubic and quartic terms in age, education categories, marital status, union status, year and region dummies, as well as dummies representing whether the workers lived in California, Florida, Illinois, New Jersey-New York and Texas.. 
Table 5. Predicted Probability of Working Long Hours (by Nativity and Years in the U.S.)

\begin{tabular}{lccccc}
\hline \hline & $(1)$ & $(2)$ & $(3)$ & $(4)$ & $(5)$ \\
& \multicolumn{1}{c}{ Occupation Percentile in the Distribution of Standard Deviation ln Earnings } \\
& 10 & 25 & 50 & 75 & 90 \\
\hline U.S. Natives & Salary Paid Workers & & & & 0.379 \\
0-5 Years & 0.285 & 0.301 & 0.328 & 0.356 & 0.303 \\
6-10 Years & 0.203 & 0.220 & 0.248 & 0.278 & 0.243 \\
11-20 Years & 0.172 & 0.184 & 0.204 & 0.226 & 0.253 \\
20+ Years & 0.175 & 0.189 & 0.210 & 0.234 & 0.283 \\
\hline U.S. Natives & 0.190 & 0.206 & 0.232 & 0.260 & 0.103 \\
0-5 Years & Hourly Paid Workers & & & 0.102 & 0.090 \\
6-10 Years & 0.101 & 0.101 & 0.102 & 0.096 & 0.080 \\
11-20 Years & 0.107 & 0.103 & 0.100 & 0.084 & 0.071 \\
20+ Years & 0.091 & 0.089 & 0.086 & 0.076 & 0.069 \\
\hline \hline
\end{tabular}

Predicted estimates using estimates from Table 4, Column 1 from Equation 4 at different values of the occupation earnings distribution. All other variables are estimated at the sample mean for each sub-group. 
Table 6. Univariate Regression Coefficients of Difference on Incidence in Long Hours on Different Occupation/Year Characteristics

Sample: Salaried Workers Only

Dependent Variable: Difference between natives and Immigrants in Long Hours

\begin{tabular}{|c|c|c|c|}
\hline & $\begin{array}{c}(1) \\
\text { All } \\
\text { Immigrants } \\
\end{array}$ & $\begin{array}{c}(2) \\
\text { Recent } \\
\text { Immigrants }\end{array}$ & $\begin{array}{c}(3) \\
\text { Earlier } \\
\text { Immigrants }\end{array}$ \\
\hline \multicolumn{4}{|l|}{ Earnings Measures } \\
\hline \multirow[t]{2}{*}{ a). In Weekly Earnings } & -0.007 & -0.015 & -0.014 \\
\hline & $(0.012)$ & $(0.017)$ & $(0.020)$ \\
\hline \multirow[t]{2}{*}{ b). In Hourly Wage } & -0.025 & -0.037 & -0.041 \\
\hline & $(0.013)$ & $(0.019)$ & $(0.021)$ \\
\hline \multirow[t]{2}{*}{ c) Difference ln Earnings } & $0.137 *$ & $0.126^{*}$ & $0.110 *$ \\
\hline & $(0.024)$ & $(0.030)$ & $(0.036)$ \\
\hline \multirow[t]{2}{*}{ d) Difference ln Wage } & $0.062 *$ & 0.043 & 0.020 \\
\hline & $(0.025)$ & $(0.029)$ & $(0.035)$ \\
\hline \multicolumn{4}{|l|}{ Long Hours Premium } \\
\hline \multirow[t]{2}{*}{ e) Long Hours Premium Linear Coefficient } & -0.011 & -0.024 & -0.015 \\
\hline & $(0.009)$ & $(0.013)$ & $(0.013)$ \\
\hline \multirow[t]{2}{*}{ f) Long Hours Premium Quartic Specification } & -0.008 & -0.008 & -0.007 \\
\hline & $(0.003)$ & $(0.002)$ & $(0.006)$ \\
\hline \multicolumn{4}{|l|}{ Earnings Dispersion Measures } \\
\hline \multirow{2}{*}{ g) Standard Deviation ln Earnings } & $0.088^{*}$ & 0.091 & 0.077 \\
\hline & $(0.041)$ & $(0.057)$ & $(0.058)$ \\
\hline \multirow[t]{2}{*}{ h) 90-10 Gap ln Earnings } & $0.065^{*}$ & 0.059 & $0.094 *$ \\
\hline & $(0.023)$ & $(0.036)$ & $(0.034)$ \\
\hline \multirow[t]{2}{*}{ i) Std Deviation Residual ln Earnings } & $0.171^{*}$ & $0.155^{*}$ & $0.154^{*}$ \\
\hline & $(0.050)$ & $(0.074)$ & $(0.071)$ \\
\hline \multirow[t]{2}{*}{ j) 90-10 Diff Residual ln Earnings } & $0.105^{*}$ & $0.090 *$ & $0.138 *$ \\
\hline & $(0.028)$ & $(0.047)$ & $(0.041)$ \\
\hline
\end{tabular}

* Denotes statistically significant at 5\% significance level. Sample: All salary and hourly paid, full time, not self employed men age 25-64 in the CPS ORG 1994-2006, Each observation is an occupation/year category $(\mathrm{N}=400)$. All regressions include year fixed effects, and each cell is weighted by the number of observations in the occupation/year category. 
Table 7. Bivariate Regression Coefficients of Difference on Incidence in Long Hours on Different Occupation/Year Characteristics

Dependent Variable: Difference between natives and Immigrants in Long Hours

\begin{tabular}{lccc}
\hline & $(1)$ & $(2)$ & $(3)$ \\
& All Immigrants & $\begin{array}{c}\text { Recent } \\
\text { Immigrants }\end{array}$ & $\begin{array}{c}\text { Earlier } \\
\text { Immigrants }\end{array}$ \\
\hline a) Long Hours Premium Linear Coefficient & $-0.027^{*}$ & $-0.034^{*}$ & $-0.027^{*}$ \\
Difference ln Weekly Earnings & $(0.010)$ & $(0.013)$ & $(0.015)$ \\
& $0.150^{*}$ & $0.134^{*}$ & $0.117^{*}$ \\
b) Long Hours Premium Quartic Specification & $(0.024)$ & $(0.030)$ & $(0.039)$ \\
& $-0.008^{*}$ & $-0.008^{*}$ & $-0.007^{*}$ \\
Difference ln Weekly Earnings & $(0.002)$ & $(0.002)$ & $(0.007)$ \\
& $0.137^{*}$ & $0.126^{*}$ & $0.111^{*}$ \\
c) Standard Deviation ln Earnings & $(0.024)$ & $(0.030)$ & $(0.036)$ \\
\hline & 0.006 & 0.027 & 0.011 \\
Difference ln Weekly Earnings & $(0.040)$ & $(0.062)$ & $(0.059)$ \\
& $0.136^{*}$ & $0.124^{*}$ & $0.109^{*}$ \\
d) 90-10 Gap ln Earnings & $(0.025)$ & $(0.033)$ & $(0.038)$ \\
\hline & 0.036 & 0.052 & 0.064 \\
Difference ln Earnings & $(0.022)$ & $(0.035)$ & $(0.035)$ \\
& $0.127^{*}$ & $0.124^{*}$ & $0.095^{*}$ \\
\hline e) Std Deviation Residual ln Earnings & $(0.025)$ & $(0.031)$ & $(0.038)$ \\
\hline & $0.105^{*}$ & 0.111 & 0.087 \\
Difference ln Earnings & $(0.048)$ & $(0.075)$ & $(0.070)$ \\
& $0.125^{*}$ & $0.120^{*}$ & $0.103^{*}$ \\
f) 90-10 Differential Residual ln Earnings & $0.067^{*}$ & 0.069 & $0.101^{*}$ \\
Difference ln Earnings & $(0.029)$ & $(0.046)$ & $(0.044)$ \\
& $0.121^{*}$ & $0.120^{*}$ & $0.091^{*}$ \\
& $(0.025)$ & $(0.032)$ & $(0.038)$ \\
\hline \hline
\end{tabular}

* Denotes statistically significant at 5\% significance level. Sample: All salary and hourly paid, full time, not self employed men age 25-64 in the CPS ORG 1994-2006, Each observation is an occupation/year category $(\mathrm{N}=400)$. All regressions include year fixed effects, and each cell is weighted by the number of observations in the occupation/year category. 
Figure 1

\section{Proportion working 50 or more weekly hours}
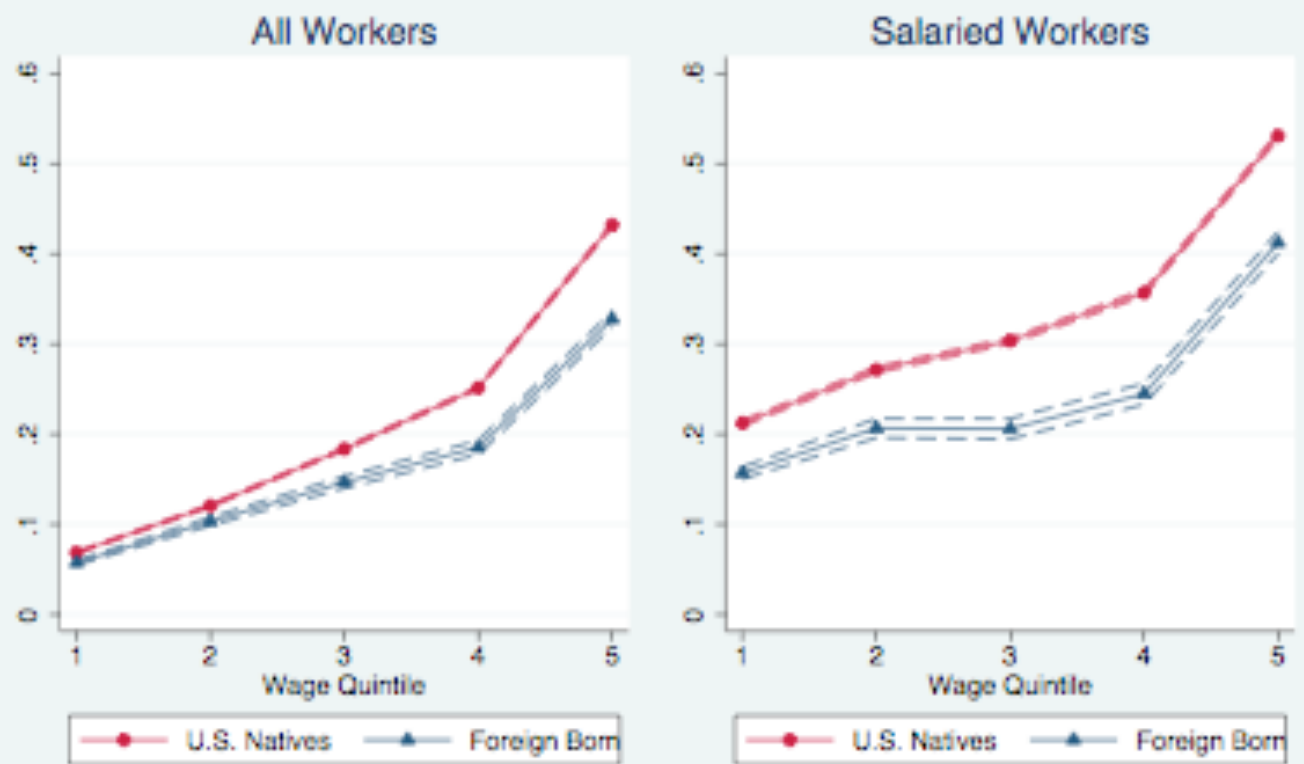

Dashed lines represent $95 \%$ confidence intervals

Source: All fultime employed males age 25-64 in the CPS ORG 1994-2006

Figure 2

\section{Predicted Differences in Probability of Working Long Hours} by Cohort of Arrival, differences with U.S. Natives
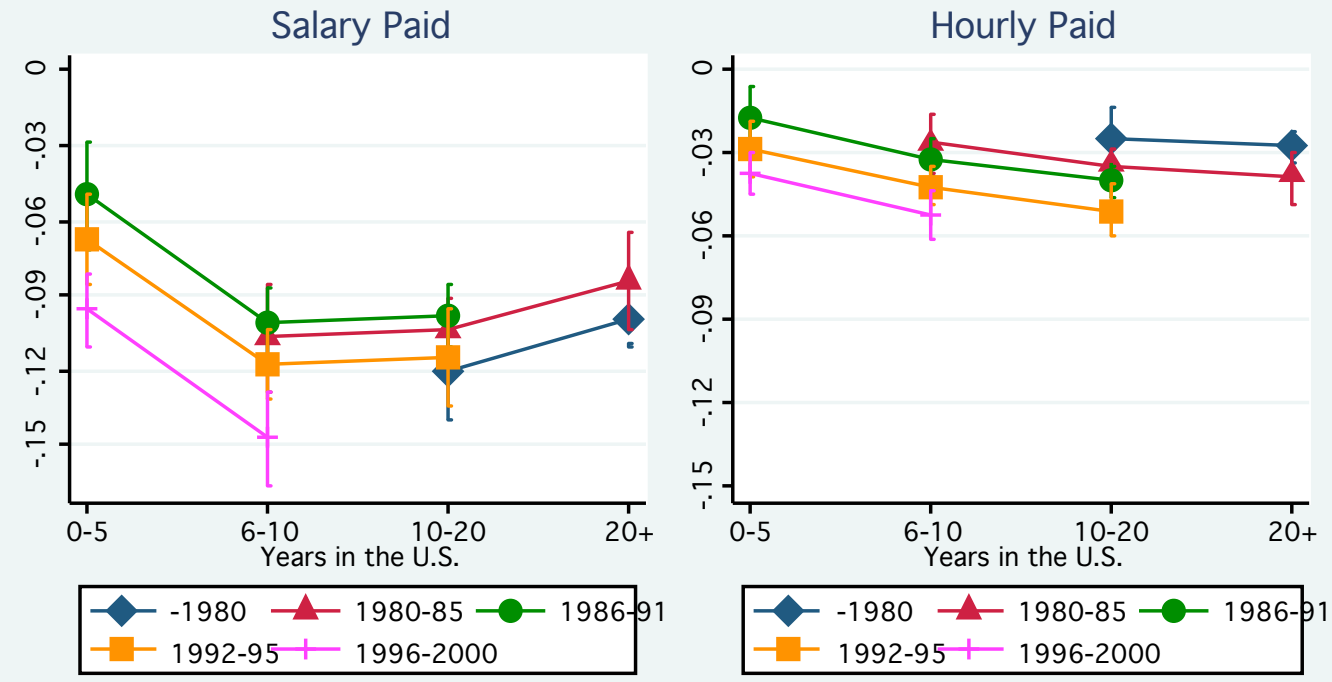

Sample: All fulltime working men age 25-64 in the 1994-2006 in the CPS ORG. Using estimates from Table 2, all other variables evalueated at sample mean. 95\% confidence intervals are represented by vertical lines at each marker. 